\title{
Technologies adopted in Diesel Locomotive Engines over Indian Railways
}

\author{
Suresh D. Mane ${ }^{1}$ \\ ${ }^{I}$ Mechanical Engineering Department, Girijabai Sail Institute of Technology, Karwar, Visvesvaraya \\ Technological University, Karnataka, India 581345
}

\begin{abstract}
Indian Railways operates 12000 trains everyday and half of them are hauled by the diesel locomotives. There are currently two types of locomotives being used over Indian Railways, the four stroke American Locomotive Company locomotives (ALCO) and the two stroke General Motors Electro Motive Division locomotives. There are commonalities as well as differences in these two locomotive engine technologies (EMD).For the past 6 decades ALCO locomotives are serving the nation and past 2 decades EMD locomotives are pressed into service. Salient features of these two technologies are not compared and as such this paper is an effort to compare the two engine technologies. All the major issues pertaining to locomotive engines are being compared in detail to have a good information of the same for a fair comparison. The paper includes the data made available by these two loco manufacturers originally from USA as well as data from diesel locomotive works, where they are currently under production.
\end{abstract}

Keywords: American Locomotive Company, Diesel Locomotive Engines, Diesel Locomotive Works, General Motors Electro Motive Division, Indian Railways

\section{Introduction}

Indian Railways (IR) is India's lifeline. IR is involved in movement of men and materials from one part of the nation to the other part covering majority of the population since 1853. Indian Railways commenced with steam traction in 1853 wherein 3 steam locomotives hauled the first train service. Due to development of diesel locomotives which had better efficiencies, speed, lesser maintenance requirements, the steam traction was discouraged and diesel locomotives were put into service. Post independence IR was nationalised and India entered into technical agreement with American Locomotive Company (ALCO) of USA and a diesel locomotive manufacturing unit was established at Varanasi in Uttar Pradesh. Initially 12 locomotives were imported from USA and due to technology transfer agreement IR started manufacturing these locomotives. These locomotives were basically 16 cylinder four stroke locomotives with turbochargers and developed 2600 hp. More than 3000 Alco locomotives have been manufactured by Diesel Locomotive Works Varanasi so far. ALCO was started in USA during 1903 and was defunct by 1969. IR has gradually increased the share of indegenisation of ALCO loco engines over the years. Due to transfer of technology the locomotives of ALCO design were continued to be manufactured by IR till the introduction of GM locomotives in 1999. In the meanwhile a new production unit viz. Diesel loco Modernisation works was established by IR at Patiala in Punjab to undertake the upgradation and rebuilding/ mid life rehabilitation of the ALCO locos. The upgradation involved enhancing the engine output from $2600 \mathrm{hp}$ to $3100 \mathrm{hp}$ and later $3300 \mathrm{hp}$. Various measures were included to increase the power output viz. Improved turbo supercharger, double helix fuel injectors for higher fuel injection, incorporating electronics in the form of sensors, micro controllers, among other measures.

In the recent decade IR entered into technical understanding with General Motors of USA to manufacture state of art two stroke engine locomotives with AC - AAC technology (AC generation and AC traction motors). These are high powered engines which develop $4000 \mathrm{hp}$ and have received wider acceptance due to increased maintenance periodicity and higher reliability. Originally few locomotives were procured in assembled condition itself and then there was technology transfer and IR commenced manufacturing these locomotives at DLW Varanasi and increased the indigenous content. During 2014-15 IR has upgraded these locomotives and now WDG $55000 \mathrm{hp} \mathrm{locomotives} \mathrm{are} \mathrm{undergoing} \mathrm{trails.} \mathrm{The} \mathrm{original} \mathrm{single} \mathrm{cab} \mathrm{design} \mathrm{of} \mathrm{the}$ GM EMD locomotive was posing visibility issues especially during long hood driving and hence IR has accordingly commenced manufacturing the locomotives with wider cab design and now twin cab locomotives have been put into service. These locomotives have self load capabilities which mean that we can start the engine and test the power developed by the engines for various rpm without the need for external load box thus saving time for maintenance.

As on 2013-14 IR has 5232 Diesel Locomotives, 4823 Electrical locomotives and 30 Steam locomotives in its fleet [1]. The Gross tonne km hauled all over IR during 2012-13 in terms of percentage was

International Conference on Recent Innovations in Civil \& Mechanical Engineering $\quad 1 \mid$ Page [i-CAM2K16] DOI: 10.9790/1684-16053020105 
$49 \%$ by Diesel, $51 \%$ by Electrical locomotives [2]. IR during 2014-15 spent Rs 35,474 Crores towards its demand for purchase of diesel and electricity. [3]. The cost of ALCO loco is Rs 7 Crores and EMD loco is Rs 15 Crores and as such maintenance of these locomotives for reliable service is a big challenge [4] This paper is an attempt to bring out the salient features of the two engines by way of their similarities and striking differences. Also the various developments undertaken by IR over its original $2600 \mathrm{hp}$ Alco engines are also described [5]. Of late the concept of fuel cell locomotives and hybrid locomotives as a measure to conserve energy [6]. Hence the need to study the technologies in diesel locomotives become all the more important in way of improving its efficiency and reducing the losses by adoption of best technological features available. At the end the various technical advancements in the world of locomotive technology is discussed.

\section{Internal Combustion Engines}

Internal Combustion (IC) engines have wide application in today's world and we have engines in range from $0.1 \mathrm{~kW}$ to large marine installations of $80000 \mathrm{~kW}$ capacity. Accordingly today the engine rpm varies from $60-100 \mathrm{rpm}$ for large capacity engines to $20,000 \mathrm{rpm}$ for racing car engines. The power to weight ratio in $\mathrm{kg} / \mathrm{kW}$ varies from 0.4 to $55 \mathrm{~kg} / \mathrm{kW}$ for slow speed engines. Specific power output ranges from $3 \mathrm{~kW} / \mathrm{ltr}$ to $100 \mathrm{~kW} / \mathrm{ttr}$ in turbocharged SI engines used in racing cars. Thus IC engines have global application and accordingly railways too use IC engines as their prime movers. The huge diesel engines of few MW capacities are powering the electrical generators which feed to the traction motors for hauling the diesel-electric locomotives.

In the recent decade IR entered into technical understanding with General Motors of USA to manufacture state of art two stroke engine locomotives with AC - AAC technology (AC generation and AC traction motors). These are high powered engines which develop $4000 \mathrm{hp}$ and have received wider acceptance due to increased maintenance periodicity and higher reliability. Originally few locomotives were procured in assembled condition itself and then there was technology transfer and IR commenced manufacturing these locomotives at DLW Varanasi and increased the indigenous content. During 2014-15 IR has upgraded these locomotives and now WDG $55000 \mathrm{hp} \mathrm{locomotives} \mathrm{are} \mathrm{undergoing} \mathrm{trails.} \mathrm{The} \mathrm{original} \mathrm{single} \mathrm{cab} \mathrm{design} \mathrm{of} \mathrm{the}$ GM EMD locomotive was posing visibility issues especially during long hood driving and hence IR has accordingly commenced manufacturing the locomotives with wider cab design and now twin cab locomotives have been put into service. These locomotives have self load capabilities which mean that we can start the engine and test the power developed by the engines for various rpm without the need for external load box thus saving time for maintenance.

\section{Similarities Between Two Engine Technologies}

The following are the similar features of both the locomotive engines. Both the engines run on diesel fuel and have 16 cylinders arranged in $45^{\circ} \mathrm{V}$ section [7]. The engine is fabricated one with steel plates and the wet cylinder liners are inserted into the cylinder blocks. The fuel injection is direct into the cylinder and has one pump, fuel injector per cylinder. Basically of them have mechanical fuel injection but the EMD engine has integrated unit fuel injection. The turbo supercharger has an intercooler and delivers air at 1.5 to 2.2 bars. The cylinder liners are wet type and they have forged alloy crankshaft with nitrided bearings. Camshafts have replaceable sections with larger diameter lobes and the engines require prelubrication once they are stopped for 48 hours or more.

Table 1: Comparison of two locomotive technologies over Indian Railways

\begin{tabular}{|c|c|c|c|}
\hline Feature & ALCO & GM ( EMD) & Remarks \\
\hline Model & $251 \mathrm{~B}, \mathrm{C}$ & GT 710 & $\begin{array}{l}\text { ALCO - } 4 \text { Stroke technology } \\
\text { GT } 710-2 \text { stroke technology }\end{array}$ \\
\hline Fuel Injector & $\begin{array}{l}\text { Separate Fuel Pump and } \\
\text { Injector }\end{array}$ & $\begin{array}{lr}\text { Combined } & \text { Pump and } \\
\text { Injector } & \text { (Unit } \\
\text { injection) } & \\
\end{array}$ & $\begin{array}{l}\text { The high pressure hose connecting the } \\
\text { pump to the injector is eliminated. } \\
\text { Thus on line failures are reduced }\end{array}$ \\
\hline Cylinder Capacity & 668 cubic inches & 710 cubic inches & $\begin{array}{l}\text { Higher cc leads to higher power } \\
\text { generation per cylinder }\end{array}$ \\
\hline Bore and Stroke & Bore 9", Stroke 10.5" & & \\
\hline $\begin{array}{l}\text { Compression Ratio } \\
(\mathrm{CR})\end{array}$ & $12: 1,12.5: 1$ & $16: 1$ & $\begin{array}{l}\text { Higher CR leads to higher thermal } \\
\text { efficiency }\end{array}$ \\
\hline $\begin{array}{l}\text { Brake mean effective } \\
\text { pressure }\end{array}$ & $\begin{array}{l}\text { 13-18 bar Continuous } \\
\text { and 4-20 bar standby }\end{array}$ & & \\
\hline Turbo supercharger & Purely Exhaust driven & $\begin{array}{l}\text { Initially mechanical } \\
\text { drive from engine , } \\
\text { later driven by } \\
\text { exhaust gas at } 538^{\circ} \mathrm{C}\end{array}$ & $\begin{array}{l}\text { In EMD locos we do not find black } \\
\text { smoke during initial cranking as the } \\
\text { excess air is supplied by turbo for } \\
\text { complete combustion of fuel. }\end{array}$ \\
\hline
\end{tabular}

International Conference on Recent Innovations in Civil \& Mechanical Engineering 
Technologies Adopted in Diesel Locomotive Engines over Indian Railways

\begin{tabular}{|l|l|l|l|}
\hline Cylinder liners & $\begin{array}{l}\text { Open grain chrome } \\
\text { plated liners }\end{array}$ & Steel Casing & $\begin{array}{l}\text { Open grain liners ensure adequate oil } \\
\text { film thickness yielding low wear rates } \\
\text { and low lube oil consumption }\end{array}$ \\
\hline Cylinder head & 4 stroke & $\begin{array}{l}\text { Stronger casting keeps thermal } \\
\text { distortion and mechanical deflection } \\
\text { to minimum }\end{array}$ \\
\hline Engine & Super bowl & $\begin{array}{l}4 \text { stroke has better thermal efficiency } \\
\text { as compared to 2 stroke. 2 stroke } \\
\text { engines are easier to crank and start. }\end{array}$ \\
\hline Piston & $\begin{array}{l}2 \text { Valves for Inlet and 2 } \\
\text { for Exhaust }\end{array}$ & $\begin{array}{l}\text { Inlet ports and exhaust } \\
4 \text { valves } \\
\text { efficiency }\end{array}$ & $\begin{array}{l}\text { There are 2 valves for intake and 2 } \\
\text { valves for exhaust in ALCO. In EMD } \\
\text { locos 2 valves are for exhaust alone. }\end{array}$ \\
\hline Valve operation & Push rod & $\begin{array}{l}\text { Overhead cam shaft } \\
\text { (OHC) }\end{array}$ & $\begin{array}{l}\text { OHC eliminates long pushrods and } \\
\text { hence the noise, friction and failures } \\
\text { due to push rods are reduced. }\end{array}$ \\
\hline
\end{tabular}

\begin{tabular}{|c|c|c|c|}
\hline Feature & ALCO & GM ( EMD) & Remarks \\
\hline Engine starting & $\begin{array}{l}\text { Battery drives the } \\
\text { auxiliary generator }\end{array}$ & $\begin{array}{l}2 \text { DC motors with } \\
\text { bendix drives which } \\
\text { rotate the ring gear on } \\
\text { flywheel }\end{array}$ & $\begin{array}{l}\text { Easy to start as the two starter motors } \\
\text { produce enough torque to crank the } \\
\text { engine. }\end{array}$ \\
\hline Radiator & Floor Mounted & $\begin{array}{l}\text { Slanted and Roof } \\
\text { mounted }\end{array}$ & $\begin{array}{l}\text { Easy Maintenance. No coolant stored in } \\
\text { Radiator Tubes when at rest. }\end{array}$ \\
\hline Radiator bonding & Soldered & $\begin{array}{l}\text { Mechanically bonded- } \\
\text { Stronger }\end{array}$ & $\begin{array}{l}\text { Mechanically bonded radiators are } \\
\text { stronger than soldered ones and also give } \\
\text { better reliability in service. }\end{array}$ \\
\hline $\begin{array}{ll}\begin{array}{l}\text { Specific } \\
\text { consumption }\end{array} & \text { fuel } \\
\end{array}$ & $160 \mathrm{gm} / \mathrm{kWh}$ & $156 \mathrm{gm} / \mathrm{kWh}$ & $\begin{array}{l}\text { SFC are very close and in tune with } \\
\text { technology in vogue. }\end{array}$ \\
\hline $\begin{array}{lr}\begin{array}{l}\text { Engine } \\
\text { maximum }\end{array} & \text { rpm } \\
\end{array}$ & 1000 & 904 & $\begin{array}{l}\text { Higher rpm results in higher power output } \\
\text { with other parameters being same. }\end{array}$ \\
\hline Idle rpm & 400 & 250 & $\begin{array}{l}\text { Low rpm results in low noise, reduced } \\
\text { fuel consumption }\end{array}$ \\
\hline Low idle feature & Not available & $\begin{array}{l}205 \text { rpm when the } \\
\text { notch is at Zero }\end{array}$ & $\begin{array}{l}\text { Low idle feature ensures lean fuel } \\
\text { consumption during idling. }\end{array}$ \\
\hline Radiator Fan & $\begin{array}{l}\text { Eddy Current Clutch } \\
86 \mathrm{hp}\end{array}$ & AC motor & Less power consumption by auxiliaries \\
\hline Maintenance & Every fortnight & Every three months & $\begin{array}{l}\text { Higher maintenance periodicity ensures } \\
\text { greater availability of loco for traffic use. }\end{array}$ \\
\hline Cylinder Capacity & & 710 cubic Inches & \\
\hline Scavenging & NA & Uniflow scavenging & $\begin{array}{l}\text { Uniflow scavenging results in better } \\
\text { scavenging when compared } \\
\text { conventional } 2 \text { stroke engines. }\end{array}$ \\
\hline Power Pulse & Every $45^{\circ}$ & Every $22.5^{\circ}$ & $\begin{array}{l}\text { EMD engines develop smooth power, } \\
\text { torque and thus less vibrations }\end{array}$ \\
\hline
\end{tabular}

\begin{tabular}{|c|c|c|c|}
\hline Feature & ALCO & GM ( EMD) & Remarks \\
\hline Engine Design & & Narrow V type & \\
\hline Crank Case Ventilation & Dc motor Blower & $\begin{array}{l}\text { Eductor System, } \\
\text { Mechanical Venturi }\end{array}$ & $\begin{array}{l}\text { Eductor system employs venturi } \\
\text { system and hence no power is } \\
\text { consumed }\end{array}$ \\
\hline Air box & & $\begin{array}{l}\text { Available with Positive } \\
\text { pressure }\end{array}$ & $\begin{array}{l}\text { The air pressure in air box is positive } \\
\text { and above atmospheric pressure. }\end{array}$ \\
\hline Crankshaft & One piece forged & $\begin{array}{l}\text { Two piece drop forged } \\
\text { joined by flange at } \\
\text { centre ( } 5 \text { and } 6 \text { main } \\
\text { bearing) }\end{array}$ & $\begin{array}{l}\text { Crankshaft manufacturing cost and } \\
\text { complexity is reduced by having } 2 \\
\text { piece crank shaft. }\end{array}$ \\
\hline Power Pack & & $\begin{array}{l}\text { Consists of Cylinder, } \\
\text { Cylinder head, piston, } \\
\text { carrier and CR }\end{array}$ & $\begin{array}{l}\text { Allows dismounting and replacement } \\
\text { of entire power pack. }\end{array}$ \\
\hline Piston & $\begin{array}{l}\text { Forged steel piston } \\
\text { crown bolted to }\end{array}$ & $\begin{array}{lll}\text { Cast } & \text { Iron } & \text { alloy } \\
\text { phosphate coated } & \end{array}$ & \\
\hline
\end{tabular}


Technologies Adopted in Diesel Locomotive Engines over Indian Railways

\begin{tabular}{|c|c|c|c|}
\hline & $\begin{array}{l}\text { aluminum alloy } \\
\text { piston (Steel Cap) }\end{array}$ & & \\
\hline Piston Carrier & No & $\begin{array}{l}\text { Piston free to rotate on } \\
\text { the carrier }\end{array}$ & $\begin{array}{l}\text { Piston rotation ensures uniform wear } \\
\text { of piston rings and better life of } \\
\text { piston. }\end{array}$ \\
\hline Connecting Rod design & & $\begin{array}{l}\text { Interlocking to reduce } \\
\text { length of engine Blade } \\
\text { Rod and Fork Rod }\end{array}$ & $\begin{array}{l}\text { Overall length of the engine is } \\
\text { reduced by the design of fork and } \\
\text { blade rod. }\end{array}$ \\
\hline $\begin{array}{l}\text { Cylinder Head rocker } \\
\text { arm adjustment }\end{array}$ & & Lash adjusters & Self adjusting lash adjusters \\
\hline Camshafts & 4 piece per bank & $\begin{array}{l}2 \text { piece sectional per } \\
\text { bank }\end{array}$ & Lighter and slender camshaft. \\
\hline Fuel Injection pressure & & $1380-2070$ bar & \\
\hline High pressure fuel lines & $\begin{array}{l}\text { Auto frettage fuel } \\
\text { lines }\end{array}$ & $\begin{array}{l}\text { Not Applicable due to } \\
\text { unit injection }\end{array}$ & $\begin{array}{l}\text { Auto frettage fuel lines also cause } \\
\text { engine failures due to engine } \\
\text { vibrations. }\end{array}$ \\
\hline Fuel pump & $\overline{\mathrm{DC}}$ & AC pump 24 lpm & $\begin{array}{l}\text { AC motor pumps are more reliable } \\
\text { than DC pumps }\end{array}$ \\
\hline Fuel filter & & $\begin{array}{l}30 \text { micron primary and } 5 \\
\text { micron secondary spin } \\
\text { on }\end{array}$ & $\begin{array}{l}\text { Micro filtration reduces ingress of } \\
\text { foreign matter and prolongs the life } \\
\text { of cylinder and pistons. }\end{array}$ \\
\hline
\end{tabular}

\section{Conclusion}

Locomotive technologies are evolving over the years. Both these technologies i.e. two stroke technology and four stroke technology have their comparative merits and demerits. The various sub assemblies, components and manufacturing technologies have been enumerated. The comparative study of these two technologies shall help the railway engineers to understand their locomotives and plan for maintenance in a better way. Engineering students studying in numerous engineering colleges do not have access to these locomotives technologies and are deprived of a suitable document comparing these technologies. This paper allows the students to understand comprehensively the locomotive engine technologies in a better manner.

From the data provided above it is seen that IR has changed with changing times and introduced new technologies. But still there are areas which IR has to look into and accordingly IR has taken up research in those areas. The following are few areas for improvement in diesel engine technologies

1. Electronic fuel injection [8]

2. Variable valve timing

3. Waste heat recovery from exhaust gases leaving the turbo super charger

4. Higher injection pressures like Common rail direct injection

Lately IR has upgraded the EMD locomotive engine from 4000 to $4500 \mathrm{hp}$ by adopting the following features.

1. Engine rpm increased from 904 to 950 .

2. Fuel delivery increased

3. Turbo speed maintained at upper limit of $21,500 \mathrm{rpm}$

4. Over speed trip assembly adjusted to incorporate enhanced rpm

5. Preventing undue vibrations of the engine.

In days to come due to advancement in technology the conventional traction systems shall be replaced with fuel cells operating on hydrogen [9]. Even in the recent past China has witnessed lower emission intensity due to electrification of its tracks and we can expect that this trend shall continue [10]. Recently Government of India has entered into understanding with General Electric to manufacture 4500-6000 hp diesel locomotives for Indian Railways. This indicates that diesel technologies shall continue for few more decades to come in India.

\section{Acknowledgement}

Author would like to thank Ministry of Railways, Government of India for the opportunity to serve the great organization and publish this article which is an outcome of his passion towards the diesel locomotives for having associated with both the Diesel Loco Sheds under South Western Railways for two years.

\section{References}

[1]. Indian Railways Statistical Publications, 2013-14, Ministry of Railways, Railway Board pp 14

[2]. Indian Railways Annual Statistical Statement, 2012-13, Ministry of Railways, Railway Board pp 199

[3]. Suresh D. Mane and N. Nagesha "Energy Security and Development" Adoption of Renewable Energy Technologies in Indian Railways" Springer Europe 2015 pp 248 
[4]. Awadesh Kumar Ahirwar et al., (2013) “ Strategy Analysis for reliability of diesel locomotives over Indian Railways” Intl. Journal of Emerging trends in Engineering and Development, Issue 3, Volume 1pp 491

[5]. Indian Railways yearbook 2014

[6]. Holger Fich H et al., "Eco Train: the Erzgebirgsbahm new hybrid railway vehicle", Transportation Research Procedia 14(2016)5757-584

[7]. GM EMD ITS- Locomotive Training Series, Student Text

[8]. Avinash Kumar Agarwal and Anirudh Gautam, (2013)“ Development of an Electronic fuel injection for 4 stroke locomotive diesel engine on Indian Railways” Directions, pp 110-119

[9]. Andreas Hoffrichter et al, (2014), "Performance evaluation of the hydrogen powered prototype locomotive, "Hydrogen Pioneer", Journal of Power Sources, 250 (2014), pp 120-127

[10]. Jicheng He, Yaozeng Li, “ Estimation of CO2 emissions of locomotives in China (1975-2005), Advances in Climate Change Research 1(1):40-45, 2010 